\title{
Research and Practice of Practice Course System Construction of Logistics Management Major in Applied Technology Colleges and Universities
}

\author{
Yanfang Pan, Dalong Liu and Liwei Li \\ Nanning University, Nanning, Guangxi, China, 530299
}

Keywords: applied technology colleges and universities; logistics management; practice

\begin{abstract}
With the rapid economic development, the modern logistics industry, as an important component of the modern economy, is rapidly developing in the global context. In the process of rapid development, the demand for logistics talents is also increasing. The logistics management shall be strengthened in applied colleges and universities, as the cradle of talent training. This paper discusses ways to cultivate logistics talents that meet the needs of society and meet market demands, and lays a solid foundation for the research and practice of practical course system construction of logistics management majors in applied technology colleges and universities.
\end{abstract}

\section{Introduction}

The development of computers and networks has brought great convenience and earth-shaking changes to the teaching work, and changed the traditional teaching methods of writing on the books and dictation, such as: the universalization of multimedia teaching, making teachers in addition to teaching knowledge of books in the teaching process. In addition, more and more rich content can be added, various types of cases and videos can be interspersed in the classroom teaching, the interaction between teachers and students can be increased, the teaching process can be more vivid, and students can understand the knowledge more easily. At the same time, in order to improve the teaching environment, colleges and universities continuously increase investment in infrastructure and equipment to enrich teaching content and expand teaching methods. Applied technology universities are no exception. In order to achieve better teaching results, to develop students' self-learning ability and innovative ability, and constantly explore teaching methods and methods, such as micro-course teaching method, flip classroom teaching method, project-based teaching, etc., have obtained good results. Figure 1 is Distribution of employment.

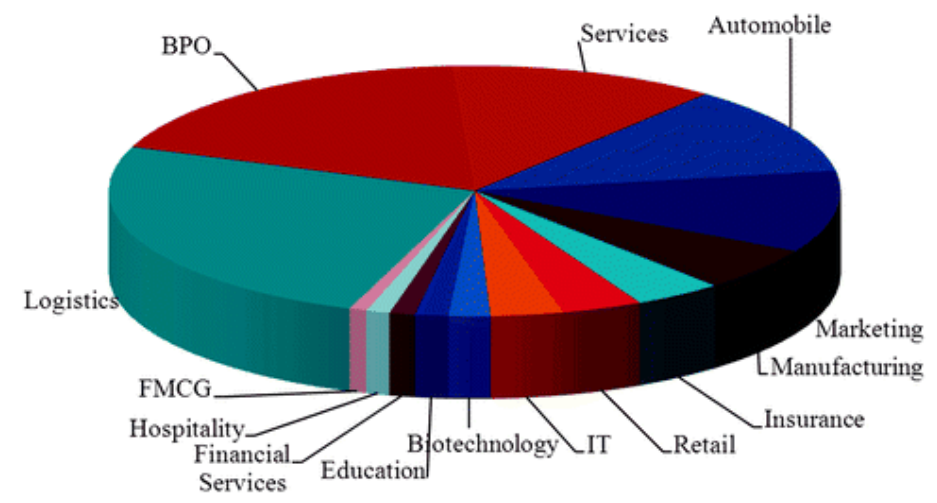

Figure 1. Distribution of Employment

The universities in our country are mainly distributed in urban areas. The economic development in the urban areas is fast. Various types of logistics enterprises have emerged after rain, especially in large and medium-sized cities, and powerful and large logistics companies have also emerged. The school has created a very good resource advantage. On the one hand, students need to practice bases. On the other hand, enterprises need professional logistics personnel. At this time, schools can cooperate with enterprises and use enterprise resources to carry out logistics teaching. Since the 
establishment of the logistics management profession, it has experienced more than 10 years of development. There are already many colleges and universities in the country that have set up logistics management majors, and the theory teaching system is improving day by day. However, the lack of practical teaching is still a problem faced by many colleges and universities. Although some schools set up practical teaching links in the curriculum system, due to the lack of experimental equipment, lack of practical training places and practical teaching bases, the practice link is still carried out in the form of theoretical teaching, which is in name only. Compared to public institutions, the funding of the University of Applied Sciences does not come from the state's financial resources. The main reason is that the founder's investment income and tuition fees are the sources of funding. Due to the lack of government funding, few schools can afford it. The construction and maintenance of various types of training rooms and laboratories can only be carried out in practice teaching.

\section{The Situation of Logistics Management Major Teaching in Applied Technology Colleges and Universities}

\subsection{Admissions}

In 2014, the State Council proposed to create conditions to phase out batches of college admissions. At present, many provinces in China have merged the second batch of undergraduates with the third batch of undergraduates to enroll in the second batch of undergraduates for admissions. This applies to the University of Applied Sciences. This is not a small shock. How to stand out from the competition for talents in various institutions is an issue that needs to be considered by Applied University. In addition, for the logistics management profession, the misunderstanding of society is also a big threat. There are many people in the society, including those who have just graduated from colleges and universities and non-logistics majors. They think that logistics is sending express delivery and they don't have a correct understanding of the concept of logistics. This kind of misunderstanding is constantly magnified, making many students do not want to apply for logistics professional, I feel no face, this misunderstanding led directly to the following situation: On the one hand, the logistics talent gap is huge; on the other hand, graduate students are reluctant to engage in the logistics industry.

\subsection{Employment}

University of Applied Technology students majored in logistics management received employment from public institutions, similar institutions, and vocational colleges. Compared with graduates of vocational colleges, the practical experience of logistics graduates at the Applied Technology University is not enough. For graduates of public institutions, the competitiveness of the Applied Technology University itself is slightly inferior and how to be competitive Winning in the market and improving the employment rate of students are also issues that need attention. At present, the logistics professional students have a relatively wide employment. There are also many logistics companies of different sizes in the society. It can be said that logistics graduates still have many choices in employment, but the actual situation is not so, because of the overtime of the logistics industry. It has become a normal state, especially when it comes to special days such as "Double 11" and "Double Twelve". It is also an overtime work. Some graduates are afraid of fatigue and other industries are selected when they are employed. These have been accepted. The loss of professional and systematic education in logistics management talents has made the gap in logistics management talents more and more relevant. The relevant data shows that the current gap for logistics management talents has reached 500,000. How to retain these talents requires us to think further.

\section{Analysis of the Construction of Teaching System for Logistics Management Major in Applied Technology Colleges and Universities}

First, to further optimize the teaching team. Among the existing faculty, excellent teachers are 
selected to participate in various types of training outside the school to learn new teaching methods to further attract students' attention in the classroom; Make up for the lack of practical experience.

Second, strengthen school-enterprise cooperation. In the process of school-enterprise cooperation, not only do teachers need to be deep-seated, but students also need to deepen the company to 'make full use of the company's resources' as far as possible to move the practice classroom to the company's workplace and allow students to carry out practical operations. Enhance students' hands-on ability.

Third, the improvement of curriculum settings. In order to better carry out teaching work, students can be arranged to conduct short-term internships in companies prior to the study of professional core and major courses. The internships are set as a course in the teaching system, and certain credits are given to strengthen the position of internships in teaching. . In addition, when setting up a course, it is necessary to consider the relationship between theoretical courses and theoretical courses, theoretical courses and practical courses, arrange preparatory courses, and increase the proportion of practical teaching courses.

Fourth, diversification of assessment methods. At present, the University of Applied Technology is subject to resource constraints in logistics teaching, and still adopts traditional assessment methods - through examination papers to test, to better understand students' mastery of curriculum knowledge, and to inspect students' practical hands-on skills. On the basis of traditional assessment methods, other assessment methods are added, such as actual operations, onboarding, and social practices.

Fifth, encourage students to participate in academic competitions, such as the National University Students Logistics Design Competition. The subject contest is no longer about a single teaching content or curriculum, but a collection of courses and a combination of multiple courses. By participating in the discipline competition, various courses can be integrated and systematically studied. At the same time, in the course of the competition, teachers can also discover students' lack of knowledge in certain knowledge, improve them in future teaching work, and better teach professional knowledge.

\section{Summary}

The University of Applied Technology should seize this opportunity to analyze and study the advantages, disadvantages, opportunities, and threats of the logistics management profession in this context, and formulate corresponding countermeasures to provide a basis for improving teaching work and training more outstanding logistics talents.

\section{References}

[1] Yanying Zeng, Zujuan Xiong, Yin Qu, Tao Chen. Practice Research on Teaching Team Construction[J]. Advanced Materials Research,2011,1290(271).

[2] Minchuan Huang, Chaoyen Wu, Jang Ruey Tzeng. Taiwan Air Force Logistics System of Research Governance[J]. Advanced Materials Research,2012,1535(393).

[3] Lijian Yu, Weiqing Mao. Study on the Model of Logistics Management of ERP Teaching[J]. Advanced Materials Research,2011,1290(271).

[4] Donald Sweeney, James Campbell, Ray Mundy. Teaching supply chain and logistics management through commercial software[J]. The International Journal of Logistics Management,2010,21(2).

[5] Yung-Chia Chang, Wen-Chih Chen, Yung-Nien Yang, Hui-Cheng Chao. A flexible web-based simulation game for production and logistics management courses[J]. Simulation Modelling Practice and Theory,2009,17(7). 